Article

\title{
Structural Model to Determine the Factors That Affect the Quality of Emergency Teaching, According to the Perception of the Student of the First University Courses
}

\author{
Isabel del Arco, Òscar Flores *(D) and Anabel Ramos-Pla (D)
}

Citation: del Arco, I.; Flores, Ò.;

Ramos-Pla, A. Structural Model to Determine the Factors That Affect the Quality of Emergency Teaching, According to the Perception of the Student of the First University Courses. Sustainability 2021, 13, 2945. https://doi.org/10.3390/su13052945

Academic Editor: Verónica Marín-Díaz

Received: 25 January 2021

Accepted: 3 March 2021

Published: 8 March 2021

Publisher's Note: MDPI stays neutral with regard to jurisdictional claims in published maps and institutional affiliations.

Copyright: (c) 2021 by the authors. Licensee MDPI, Basel, Switzerland. This article is an open access article distributed under the terms and conditions of the Creative Commons Attribution (CC BY) license (https:/ / creativecommons.org/licenses/by/ $4.0 /)$.
Department of Pedagogy, Faculty of Education, Psychology and Social Work, University of Lleida, 25001 Lleida, Spain; isabel.delarco@udl.cat (I.d.A.); anabel.ramos@udl.cat (A.R.-P.)

* Correspondence: oscar.flores@udl.cat

\begin{abstract}
A quantitative study was conducted in order to know, from the perspective of university students, the relationship between the quality perceived (QP) during the period of confinement derived from the SARS-CoV-2 virus, with the variables teaching plan (PL), material resources (MR), interaction processes (IN), and the affective-emotional component (EM). An online questionnaire was designed, directed to students from 20 universities in Spain, with a total participation of 893 individuals. The results indicate that the perception of the students on the quality of online teaching is directly associated with the material resources provided by the professors and the professorstudent interactions. However, this perception does not have any direct effect on the planning or the emotional state or affectation created by the unprecedented situation of confinement. Among the conclusions, we highlight the need for the universities to apply models of support and tutoring, especially for students in their first years at university, to develop competences such as autonomy, digital competence, and self-regulation, and the need for a change of approach of the students and the professors based on the new normality we are currently experiencing.
\end{abstract}

Keywords: virtual classrooms; teaching methods; online learning; quality of teaching; crisis intervention

\section{Introduction}

The pandemic suffered in 2020 due to the COVID-19 virus [1,2] has caused great havoc in diverse areas of society (health, social, economics, etc.).

Overnight, every student from every educational stage stopped attending education centers due to the absolute confinement declared in many countries. In the area of higher education, the solution adopted was the suspension of in-person teaching and the establishment of a virtual format to ensure the continuity of the academic year. This implied an abrupt and urgent change, defined by [3] as "emergency remote learning", which every institution had to confront [4].

Many educators were not prepared to face this situation. According to the report by Xarxa Vives [5], the university system does not yet have all the elements needed for a fast transition to the type of training or education that is more in line with the needs of 21st Century students, as the methodologies utilized are still mostly traditional.

As a result of the new situation, the education models were diversified to devise this new and widespread type of remote learning: from the professor who replicated exactly the in-person classes utilizing tools such as videoconferencing [6], to the professor who modified the entire teaching plan to adapt the methodological and evaluation strategies to the new context. Many factors had an effect on the decision by a professor to adopt one manner of teaching over another: experience, the level of digital competence, the availability of the resources, the ability to adapt, resilience, and the bravery of each individual to risk and try new things [7,8]. 
On the other hand, this unprecedented situation also had consequences on the students. Studies such as $[9,10]$ have analyzed the efforts made by the students to adapt to a new modality of training/learning that demanded a greater discipline and commitment [11]. Other variables could also be added, such as social isolation, the possibility to have an internet connection, the financial situation, and the anxiety associated with the pandemic. These matters left the students in a situation of digital divide as a result of many factors, promoted by the situation of confinement derived from the pandemic [12-14].

Studies show that the students felt lost in the emergency teaching created, essentially because they had not yet developed their ability to self-regulate and did not have learning autonomy [15]. Along the same line, the students, when deprived from face-to-face contact, were basically faced with an expository type of instruction, as the manner of transmitting information, isolated and disoriented with materials and activities that they did not know how to approach, resulted in the increase in lack of involvement, disorientation, and comprehension.

Multiple and abundant studies were conducted that identified the most important elements for the development of a virtual type of teaching with the maximum assurances of quality.

\section{Theoretical Modelling Proposal and Hypotheses}

It can be asserted that there is currently a certain consensus in that the quality of a product or service must be determined by the user and not by the producer [16]. In the area of education, and more specifically in higher education, it could be argued if the students could be considered as the sole users, the receiving agent of the teaching process, or if the professor should also be considered, because in the end, the educator is also immersed in a broader system.

It is evident that the student is a key agent in the process of teaching-learning. In fact, the new scenarios are based on participative learning (either in-person or virtual). This perspective promotes different types of methodologies that allow for the development of competences oriented towards the autonomy of the students [17-22].

On their part, educators are also key protagonists in this process [23-25]. It is they who are the producers of the service created, but at the same time users of a broader system. If this system promotes their professional training and development, they will acquire competences that will allow them to make decisions and execute them with solid and practical theoretical foundations.

Teaching that is not in-person, but mediated by technologies, cannot replicate the in-person classroom model, as they are completely different scenarios. Thus, since a few years ago, the elements needed for the development of quality online teaching have been studied in the pedagogic and didactic areas of study. In this way, quality teaching is defined as that which fulfills its purposes effectively and, therefore, student learning occurs [26-28]. In addition, it promotes the processes that allow achieving the objectives and purposes. Thus, quality in teaching refers to both learning outcomes and the educational process (quality in the learning process).

Focusing on the perspective of the students, the literature has shown multiple factors that are described as being important for them to consider an online course as high quality [29-32]: the space-time flexibility offered by this learning modality, the savings due to not having to travel to the place of study and having the materials available online, that the resources are available and well designed, the easiness to connect to the Internet, a class interface that is well designed, that the characteristics of the learners and the context are considered, that the time required for completing the tasks be adequate, the motivation itself to take the course, that a feeling of isolation is avoided, that the educator or instructor does not take a long time for providing feedback or technical support, that the instruction methods are not monotonous, and that interaction and discussion among participants is favored. 
For conducting the present research study, we will focus on four variables out of all the possible factors: teaching plan, the material resources, the interaction processes, and as a novelty, we introduce the variable "affective-emotional component", as it is interesting to know and understand how this component affected the perception of quality of the course, according to the students, in completely unprecedented times due to the pandemic and the abrupt interruption of in-person classes. At the end of the theoretical argumentation of each variable to be considered, a specific hypothesis will be formulated for each of the variables described.

\subsection{Teaching Plan}

The teaching plan is understood as the previous process performed by the professor before the first class, which encompasses aspects such as how to structure the course well, clearly define the course calendar, the tasks to perform, the submission times, the system of evaluation, tutoring times, etc. [30,31]. In general, it is considered that the professors do not plan with a flexible perspective and with possibilities of adaptation to diverse situations, or take advantage of the possibilities offered by technology. Perhaps this is related to the generalized conception that virtual teaching is second-class with respect to in-person teaching. Professors have not considered the addition of technologies in university teaching as an opportunity to create improved quality teaching that could even substitute the online meetings [33-36].

In fact, the new Digital Education Action Plan 2021-27 from the European Commission focuses on digital education as a fundamental medium for the necessary transformation in every sector of society, understood as a key instrument for the fair and inclusive recovery of every citizen [37]. Therefore, the educator will have to increasingly understand and plan courses under the paradigm of considering himself or herself as a guide, mediator, or adviser who creates spaces and opportunities so that the student propitiates learning that is autonomous, critical, and reflexive [38,39].

Hypothesis 1 (H1). An adequate teaching plan has a positive influence on the perception of the quality of online teaching.

\subsection{Material Resources}

Studies have shown that students establish a direct relationship between teaching quality and the materials utilized for developing the different teaching-learning processes [40-45].

It is important that teachers consider this to promote the process of quality learning. Thus, when providing material resources (referring to the mobilization of a diversity of materials, varied and easily accessible), they should consider that different formats must be utilized (text, visual, and audiovisual), offer current documents related with reality, invite the students to share their own resources, facilitate their consultation, etc. However, scientific literature shows that university teaching is limited to the basic use of resources, maintaining a pedagogic model of the educator as a broadcaster of knowledge, and utilizing a limited spectrum of technological tools [46-48].

Hypothesis 2 (H2). The material resources provided have an effect on the perception of the quality of online teaching.

\subsection{Interaction Processes}

A third fundamental pillar of online teaching is the interaction process. In the virtual teaching scenario, the student does not have the teacher in front to resolve any doubts. For this reason, it is vital that the course includes sufficient mechanisms so the student feels supported and backed by the professor $[16,21,40,49,50]$.

As of today, advanced technology is available for creating interaction and collaboration spaces between the students and professor. The problem, therefore, is not the lack of 
tools, but the ability to use them. If it is accepted that the students tend to have a good level of competence on ICT tools, especially at the levels of communication, interaction, and collaboration [51], the situation that has risen has provided evidence about the low digital competence of the educators. According to the OCDE [52], only $40 \%$ of the educators at every level of education considered themselves to be prepared to use digital technologies to teach.

Hypothesis 3 (H3). The professor-student interactions have a direct effect on the perception of the quality of online teaching.

\subsection{Affective-Emotional Component}

As mentioned above, an important and novel variable is added, given the unprecedented situation in which online teaching took place, and the possible emotional affectation that the effects of the pandemic could have had on the immediate and global environment. In Figure 1, the relationships between the latent variables are graphically explicit, expressing the hypotheses stated for each relationship.

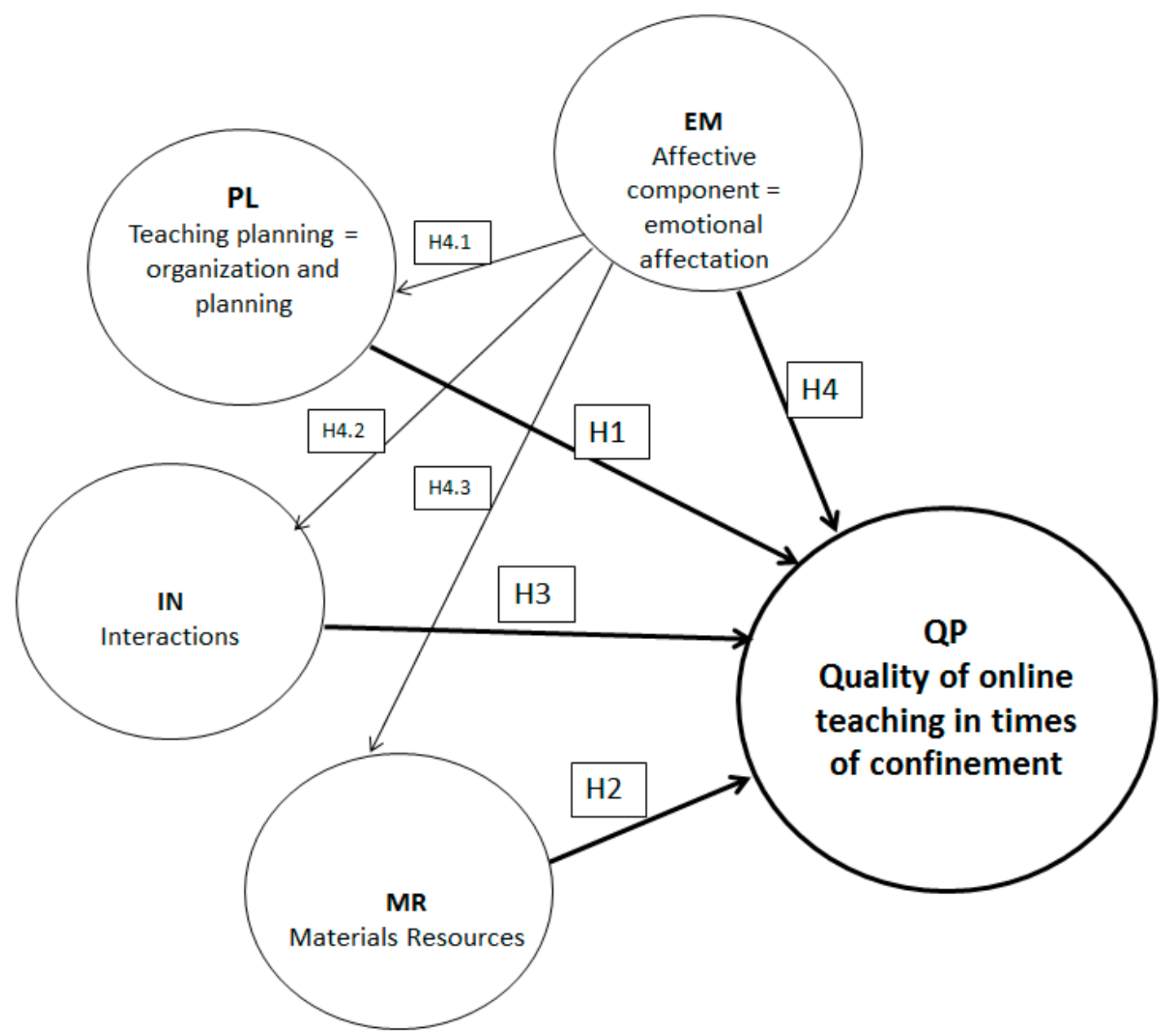

Figure 1. Model: variables which have an effect on the perception of the quality of online teaching in times of confinement.

It is a proven fact that motivation and the mood of the students have a direct relationship on learning and the perception one could have of the quality of teaching [53-55].

Hypothesis 4 (H4). The emotional state has a direct influence on the perception of the quality of online teaching. 
The emotional state and the affectation of the pandemic, on the emotions of the students, have a direct effect on the variables considered, that is, about how they perceive and evaluate the teaching plan, the interactions that took place and their need, and the perception on the material resources provided by the educator for online teaching.

Hypothesis 4.1 (H4.1). The emotional state has an influence on how the teaching plan is perceived.

Hypothesis 4.2 (H4.2). The emotional state has an influence on teacher-learner interactions.

Hypothesis 4.3 (H4.3). The emotional state has an influence on the perception on the material resources provided.

\section{Materials and Methods}

\subsection{Methodological Approach: Research Background}

The present study is part of a broader study (del Arco, I.; Silva, P.; Flores, O. University Teaching in Times of Confinement: The Light and Shadows of Compulsory Online Learning. Sustainability 2021, 13, 375. https://doi.org/10.3390/su13010375) conducted with students from different public universities in Spain. With the participation of students of different levels and university studies, we wanted to analyze the factors that had an effect on the creation of quality teaching during the period of confinement. We were interested in knowing the opinion of students on the emergency teaching that took place exclusively online. That broader study provided evidence that the students enrolled in their first years at university provided the lowest scores for their perception on the quality of online teaching.

This is where the need arose to delve into the matter, with the objective being to organize the variables considered as intervening in quality teaching, with the idea of detecting their level of affectation, according to the perception of the students in their first academic years, when this online teaching was conducted in an unprecedented situation of confinement.

To meet this objective, a descriptive study was conducted based on a non-experimental design, with a model of variables (Figure 1) that was designed following the different theoretical references. The idea was to corroborate this model, aside from discovering the causal relationships of the variables between them.

\subsection{Data Collection and Sample}

To collect the data, an ad-hoc structured questionnaire (to arrange or view the questionnaire, send the request to dots@udl.cat. This questionnaire is a tool built ad hoc thanks to funding from the DOTS-UdL Chair) was created, comprised of three parts: the first part contained a brief introduction, which explained the nature of the research study; the second part collected the basic identification data: gender, academic year, and university degree studied; and the third part contained the questions on the items that explained each of the latent variables referred to in the model presented, and which were the result of the scientific literature review performed.

The data collection was conducted through the application of the online questionnaire, and was based on a random probabilistic sampling of the first- and second-year students from 20 public universities in Spain. The 20 universities that make up the sample are state public, and all the participating students had to adapt to emergency online teaching during confinement. The questionnaire was sent to the students through the collaboration of colleagues from each of the universities. A confidentiality and data protection declaration was presented, and the participants gave their consent to participate after an exhaustive explanation of the project

In the end, a total of 896 students participated in the study. This sample can be considered as statistically representative of the study population, according to the assumption of 
a large $\mathrm{N}(>20,000)$, and maximum variance $(p=\mathrm{q}=50 \%)$, so that with a level of confidence of $95 \%$, the maximum margin of error was 3.5 , which was deemed adequate.

The breakdown of the participants according to academic year was $57.5 \%$ first-year students and $42.5 \%$ second-year students. As for gender, $73.1 \%$ were women, as compared to $26.9 \%$ men, and according to the degrees, the social sciences and humanities predominated with $51.4 \%$, followed by health sciences, $31.3 \%$, and science and engineering, $17.3 \%$.

\subsection{Measurements}

In the present study, five latent variables were defined (see Table 1):

- Organization and Planning (PL), which at the same time is composed by two subdimensions:

- Clear and shared organization (CPL)

- Workload (PLW)

- Interactions (IN):,which at the same time is composed by two sub-dimensions:

- $\quad$ Active and on-time response (INR)

- Interactions between equals and the educator (INE)

- Material Resources (MR)

- Emotional Affectation (EM)

- Quality of the online teaching in periods of confinement (QP).

Table 1. Description of the items set for each latent variable.

\begin{tabular}{llll}
\hline Latent Variables & & \\
\hline & & &
\end{tabular}

A questionnaire was utilized for data collection, composed of 20 items with a Likert-type response scale ranging from $0-4$, with $0=$ nothing/null, to $4=$ much/always. These 20 items are distributed into the five latent variables considered: $\mathrm{PL}=5 ; \mathrm{IN}=4 ; \mathrm{MR}=2 ; \mathrm{EM}=5$; $\mathrm{QP}=4$.

The questionnaire was subjected to a content validation process through the expert's judgement method. For this, eight judges participated, who were experts on the subject, and three representatives of the sample. These judges analyzed the different items of the questionnaire, following the validation criteria of pertinence, univocality, and relevance. The mean and standard deviation of the experts' judgments are calculated for each criterion and for each item. The Lawshe content validity index (CVI) was then calculated. The IVC reaches values between $[-1,+1]$ and an item with a negative IVC can never be admitted. 
From the CVI, the content validity ratio was calculated for each item (IVR) with values on the scale $[0,+1]$ and in our case, to accept an item, it had to have a VCR $>0.58$.

For the statistical analysis, the software program R (v. 4.0.2) was utilized, together with the lavaan libraries for the fitting of the model, and semPlot for the creation of the figures.

The structural equations model (SEM) was utilized to prove the validity of the theoretical model proposed, starting with the data available from the sample. The methodology based on the SEM is one of the most regarded procedures that can be utilized to explain many current phenomena in education. Through the SEM, we can prove and estimate relationships that are presumably causal between the latent variables from measurement and structural perspectives [56-58].

The level of significance set for the study was the commonly used $5 \%$ (significant if $p<0.05)$.

\section{Results.}

\subsection{Analysis of the Psychometric Properties of the Measurement Model}

To analyze the reliability, Cronbach's Alpha was utilized (Table 2). The coefficients found obtained values higher than 0.70 , and this indicates an acceptable degree of reliability between the items that shape the latent variable.

Table 2. Reliability of the latent variables: Cronbach's "Alpha".

\begin{tabular}{ccccc}
\hline & \multirow{2}{*}{ ITEMS } & \multirow{2}{*}{ “Alpha” Coeffi. } & \multicolumn{2}{c}{ CI 95\% } \\
\cline { 4 - 5 } & & & Lower Lim. & Upper Lim. \\
\hline PL & 5 & 0.72 & 0.74 & 0.77 \\
IN & 4 & 0.73 & 0.76 & 0.79 \\
MR & 5 & 0.76 & 0.78 & 0.81 \\
EM & 4 & 0.79 & 0.77 & 0.82 \\
QP & 0.84 & 0.85 & 0.87 \\
\hline
\end{tabular}

Table 3 shows the summary of the indices of adjustment utilized to analyze the structure of the relationships of the variables studied. As can be observed, the RMSEA value, as well as the limits of its confidence interval at $90 \%$, were lower than 0.08 , which indicates an acceptable fit. At the same time, the CFI and TLI values were close to 0.90, and the SRMR was found to be below 0.08 .

Table 3. SEM: Goodness-of-fit indices.

\begin{tabular}{ccccc}
\hline RMSEA & SRMR & CFI & TLI & Chi $^{2} / \mathbf{g l}$ \\
\hline $0.075(0.071-0.080)$ & 0.062 & 0.909 & 0.890 & $900.296(p<0.0001)$ \\
\hline
\end{tabular}

With these indices, it can be concluded that the model fit is good, and therefore, the relationships between the latent variables are partially confirmed.

The regression indicates where we can find the causal relationship between which variables (Table 4). It is interesting to note that between EM with PL and MR, a causal relationship is observed that is the inverse from what had been established in the initial model.

\subsection{Analysis of the Structural Relationships and Contrast in the Hypotheses Proposed}

To verify if the theoretical structure defined for the latent variables can be corroborated with the information from the sample, a structural equation model (SEM) is utilized.

The analysis of the structural relationships and the contrast in the hypotheses posed is shown in Table 5.

According to the data obtained, there is a direct relationship between MR and QP, and IN and QP, so that $\mathrm{H} 2$ and $\mathrm{H} 3$ are accepted. Thus, the perception of the students on the quality of online teaching is directly related with the material resources provided by the professors and the professor-student interactions during the teaching-learning process. 
Table 4. Structural equation model: regression.

\begin{tabular}{cccc}
\hline Latent Variables: & Estimation & Standard Error & $\mathbf{z}$ \\
\hline QP & & & \\
MR & 1.946 & 0.151 & 12.924 \\
IN & 0.898 & 0.036 & 24.981 \\
\hline IN & & & \\
EM & 0.142 & 0.034 & 4.217 \\
\hline EM & & & \\
PL & -0.259 & 0.035 & -7.29 \\
MR & -0.093 & 0.017 & -5.599 \\
\hline
\end{tabular}

Table 5. Evaluation of structural models.

\begin{tabular}{ccccc}
\hline Hypothesis & Structural Relationship & Coeff. & t-Value & Contrast \\
\hline H1 & $\mathrm{PL} \rightarrow \mathrm{QP}$ & 0.08 & 3.71 & $\mathrm{NS}$ \\
$\mathrm{H} 2$ & $\mathrm{MR} \rightarrow \mathrm{QP}$ & 0.97 & 12.03 & $\mathrm{~S}$ \\
$\mathrm{H} 3$ & $\mathrm{IN} \rightarrow \mathrm{QP}$ & 0.93 & 22.32 & $\mathrm{~S}$ \\
$\mathrm{H} 4$ & $\mathrm{EM} \rightarrow \mathrm{QP}$ & 0.09 & 5.87 & $\mathrm{NS}$ \\
$\mathrm{H} 4.1$ & $\mathrm{EM} \rightarrow \mathrm{PL}$ & -0.36 & 8.21 & $\mathrm{~S}$ \\
$\mathrm{H} 4.2$ & $\mathrm{EM} \rightarrow \mathrm{IN}$ & 0.12 & 6.65 & $\mathrm{~S}$ \\
$\mathrm{H} 4.3$ & $\mathrm{EM} \rightarrow \mathrm{MR}$ & -0.27 & 13.21 & $\mathrm{~S}$ \\
\hline
\end{tabular}

S: Supported; NS: Not Supported.

However, there is no relationship between PL and QP, and EM and QP. Thus, H1 and $\mathrm{H} 4$ are rejected, as they obtained a low coefficient ( 0.08 and 0.09 , respectively). We can thus conclude that neither the planning of the professors, nor the emotional state or emotional affectation created by the unprecedented situation of confinement had any direct effect on the perception of the quality of online teaching.

After a more in-depth analysis of the latent variable (EM), it was evidenced that there was a direct relationship, although weak, between EM and IN. Thus, H4.2 is accepted, indicating that the emotional state of the moment had an influence on the professorstudent interactions.

The subhypotheses $\mathrm{H} 4.1$ and $\mathrm{H} 4.3$ are also accepted, although the relationship between the latent variables is not direct, as it could be initially thought, but inverse. That is, there is an inverse relationship between EM and PL, and EM and MR. Additionally, this relationship is bidirectional, in that both variables affected each other in an inverse manner. Good planning and good material resources provided by the professors are perceived better when the emotional state is lower.

Figure 2 shows the final scheme of the relationships established between the variables studied.

When analyzing the model proposed, and according to the resulting flow diagram, it is shown that the quality of online teaching during confinement was influenced by the material resources utilized and the interactions produced. It does not seem to have any effect on the perception of quality or the planning and organization of teaching, or the mood or the emotional affectation at the time.

The negative causal relationship between planning and emotional affectation leads us to remark that better planning and organization was perceived when the mood is low. Additionally, this relationship, as previously mentioned, is bidirectional, as an inverse causal relationship exists between both variables.

The same was observed between emotional affectation and the materials; thus, we can conclude that adequate material resources help to reduce the levels defined in the emotional affectation. A bidirectional influence was also found in both variables. When observing the diagram, the bidirectional relationship between PL and MR is observed, with a high direct effect $(0.87)$. Therefore, the students consider that good planning is linked to the material resources provided, and vice-versa. 


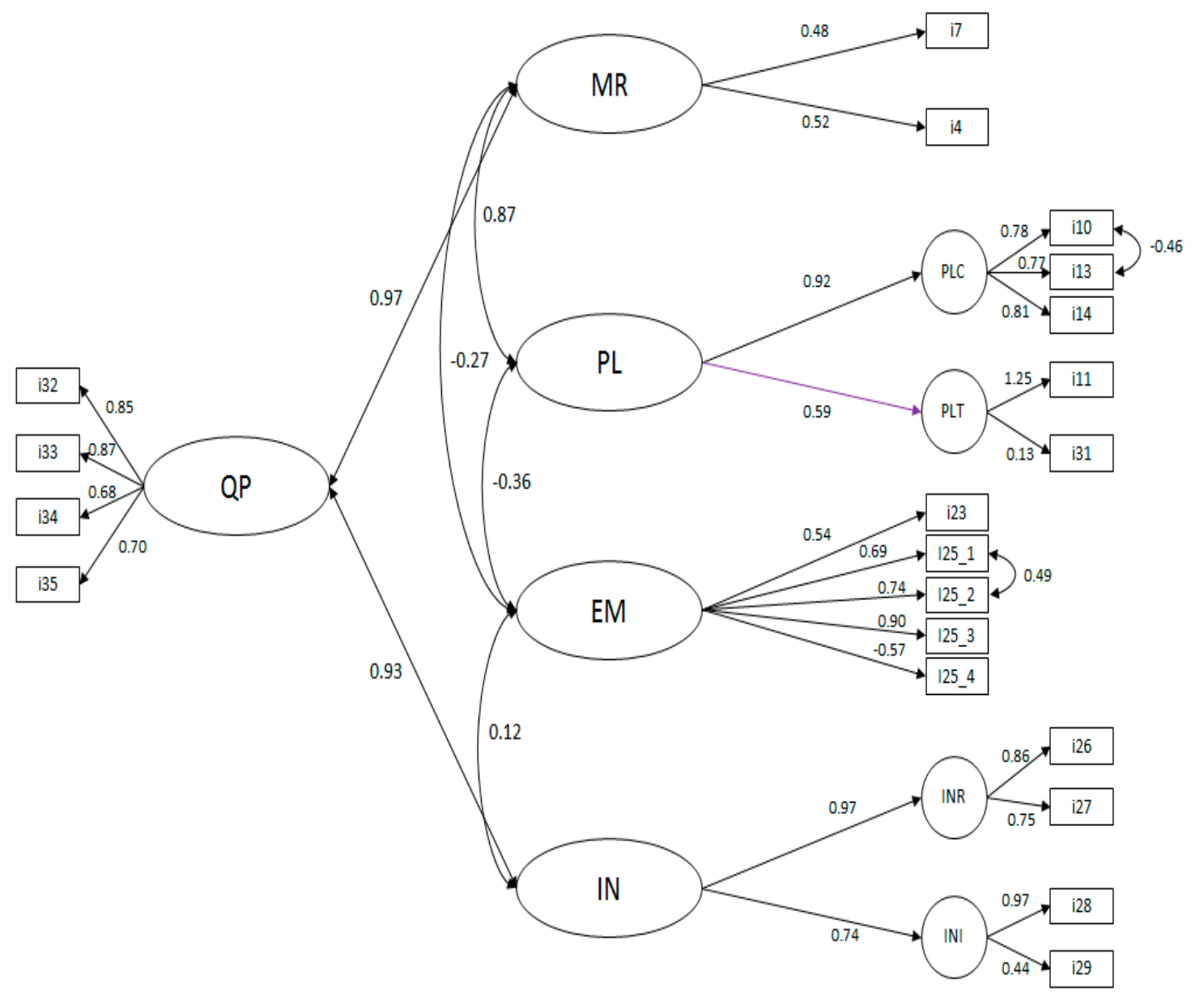

Figure 2. Flow diagram: SEM. Created with the R package semPlot.

\section{Discussion}

The main foundations of quality virtual teaching are sustained by the organization, the content, the tutorship, the evaluations, and the technological environment $[16,21,40,49,50]$. Additionally, quality virtual teaching should contribute to the shifting away from traditional/instructional teaching. This is related to moving away from a model of teachinglearning focused on the role of the professor as the broadcaster of content, towards a model based on significant, profound, and functional learning, focused on the learners.

The university students, in general, were not satisfied with the online teaching conducted during confinement, as described by [59]. The same authors pointed to the need to continue delving into how to improve the class sessions mediated by the technological and digital resources, and that the students in their first years at university were the ones who evaluated this experience the lowest.

In the present study, it was evidenced how the quality of online teaching perceived by the students in their first academic years of their degrees was directly associated with the interactions generated between the professors and the students, and with the material resources provided. The causal relationship was very high ( 0.93 and 0.97 , respectively).

The student-professor interactions are very important, especially during the first academic years at university. In this study, the importance of these interactions on the virtual classes was verified. The variables that were best evaluated were the speed of the response of the professor and that he or she promoted positive interactions (with him/her and between the groups of equals). Additionally, that the professor fomented the active participation of the students and promoted work between equals was evaluated highly. The students in their first university years are starting new educational processes (that are different from other education stages), and deserve special attention. A system is thus 
needed in which support for the students is promoted in online teaching (especially in the first and second academic years), thereby fostering the mechanisms needed to invigorate and implement online tutorship [60,61].

Due to the data obtained, the need grows to provide a variety of material resources that are motivational, innovative, and easy to access, use, and download. However, some studies [62] affirm that professors used a scarce variety of technological resources (static visual presentations, virtual platforms such as Virtual Campuses or cloud storage) Additionally, although the students can easily use the different tools, they do not know about the great variety that exists, and need clear and adequate guidelines from the professors.

An existing constant feature of university education is the general concept of teaching, as a process of transmission of content $[44,63]$. Thus, technologies are utilized in university teaching in a limited manner, as they are only utilized as a resource for maintaining the traditional pedagogical model. In this sense, the spectrum of technological tools is very limited, although it guarantees the presentation of content in a unidirectional manner $[45,46,64]$.

On the other hand, the students did not show any direct relationship between planning and organization of teaching and quality perceived. An explanation of this could be that planning is perceived as a task that must be performed by the professors only, which is shown in the teaching guides at the start of the academic year. Thus, when in-person teaching was shifted to cyberspace, planning, which was already performed in the inperson format, was not considered as something that could have an effect on the quality of online teaching. This variable is perceived, by the students, as non-modifiable and something they do not have an effect on.

However, in order to transfer in-person teaching to an online format, it is necessary to create a new plan to adapt it to the new format. There are many studies that affirm that this new planning was not done $[3,65,66]$, although a specific adaptation was made regarding evaluation. Re-planning the evaluation to adapt it to the online format was perceived negatively among the students, as it modified the explicit conditions in the guidelines presented at the start of the academic year [67].

Lastly, the discussion will now focus on a variable that was added to this study as a latent variable, and which appeared due to the exceptional conditions within which this online teaching was conducted, none other than the massive confinement of this population. This variable refers to the emotional state or emotional affectation (EM) generated in the students when faced with this situation. As already commented, the emotional state did not have a direct effect on the quality perceived about the teaching. However, there was an inverse relationship between the teaching plan, the interactions conducted, and the material resources provided for quality online teaching.

Author like [53-55] insist on the direct relationship between motivation and mood of the students with learning and the perception they have on the quality of teaching. However, in this study, we point to the resilience of the students who accepted the global situation, and their emotional state only had an inverse influence on planning and the material resources provided, but not on the overall perception on the quality of online teaching.

\section{Conclusions, Limitations and Future Lines of Research}

\subsection{Conclusions}

The students in their first years at university were the ones who perceived online teaching during confinement as low in quality. The need for greater interaction with the professor could be the result of a greater dependence on this figure and a lower development of the competences of personal autonomy and self-regulation.

Tutoring and support by and from the professors of the students becomes more necessary, and this needs increases even more with online teaching.

This support should place more emphasis on the emotional state of the student, as it affects the quality and quantity of the interactions. Thus, designing and putting into 
practice effective tutoring action plans that are profound and of high quality could help the students develop competences.

The material resources that are provided are very important. The teaching platform, the variety of means available to the students, and even the possibility that they themselves provide proposals are factors that will help improve the quality of online teaching. For this, the teacher's training on digital competences will be needed, with special emphasis on digital didactics, for the planning and activities and the use of motivational and multivariate resources.

One of the main conclusions is that planning does not have an effect on a quality teaching model, according to the perspective of students enrolled in their first years at university. The students understand that the planning conducted for in-person teaching is non-modifiable, and should be respected in online teaching, as it is a contract created for each class during enrolment.

If planning is not a factor that should be considered, the interactions must be. The students expect that motivational devices will be used that are easy to access, and that the professors answer in a fast manner.

\subsection{Limitations of the Investigation}

Although this study has some limitations, these do not invalidate the results obtained, as they indicate a clear trend of how online teaching in the first years of university teaching should be focused. Thus, a possible limitation is a certain disequilibrium in the sample, as there was a greater presence of women, who in the present study were shown to be more affected emotionally by the situation of confinement (72\% as compared to $28 \%$ of men), as indicated by their finding themselves more sad and worried about the situation, with uneasiness and anxiety and with the desire for the confinement to end. Additionally, most of the students were enrolled in university studies in the area of Social Sciences and Humanities. These sample characteristics could make us think that the results could have been influenced by the perception of a sample that was mostly female who are enrolled in specific university studies.

\subsection{Future Lines of Research}

It is evident that there is a need to delve into successful online teaching proposals that guarantee high quality teaching, so that students and the professors themselves think of it that way as well.

A university teaching model is needed with the ability to adapt to different contingencies created by situations of crisis and that have an effect on the develop of competences in general, and digital competences in particular.

In the document by the European Union, "a renewed EU agenda for higher education", item 4 establishes that the "higher education institutions should be encouraged to re-think the manner in which to think of learning and teaching, and to encourage, in particular, an approach centered on the student, learning based on collaboration and experimentation, in inclusive learning environments, and the use of digital technologies". Item 17 expands on this, encouraging measures to improve the digital competences of academic staff, including digital pedagogy and digital competences in their own disciplines", and this as expressed in item 30, "to foment the development of innovative pedagogies to help higher education centers to apply encompassing strategies of digital learning $(\ldots)$ exploring the preparation model of digital learning [34].

Thus, the lessons learning with emergency online teaching, conducted during the period of confinement, should serve as the indisputable basis for redesigning the teachinglearning processes. In-person teaching and online teaching should have clear concepts for competence training, with the commitment from the educator, as well as the students. In summary, online teaching should be considered within the same quality parameters as in-person teaching. 
Author Contributions: Conceptualization, I.d.A. and Ò.F.; methodology, I.d.A. and A.R.-P.; validation, I.d.A., Ò.F. and A.R.-P.; formal analysis, I.d.A.; investigation, I.d.A., Ò.F. and A.R.-P.; data curation, I.d.A.; writ-ing-original draft preparation, I.d.A., Oे.F. and A.R.-P.; writing-review and editing, I.d.A., Ò.F. and A.R.-P.; visualization, I.d.A., Ò.F. and A.R.-P.; supervision, I.d.A. All authors have read and agreed to the published version of the manuscript.

Funding: This study has been subsidized by the DOTS University Chair (Chair for the Development of Healthy and Sustainable Organizations and Territories), approved by agreement No. 193/2017 of the Governing Council of the University of Lleida on 19 July 2017.

Institutional Review Board Statement: Ethical review and approval were waived for this study, due to not involving personally identifiable nor sensitive data.

Informed Consent Statement: Student consent was waived due to not involving personally identifiable nor sensitive data.

Data Availability Statement: Data presented in this study are available on request from the corresponding author. The data are not publicly available due to the conditions of the project contract with the funder: DOTS University Chair (Chair for the Development of Healthy and Sustainable Organizations and Territories).

Acknowledgments: Thanks to the DOTS Chair of the University of Lleida for their support in carrying out this study.

Conflicts of Interest: The authors declare no conflict of interest.

\section{References}

1. World Health Organization. Coronavirus Disease 2019 (COVID-19). Available online: https://apps.who.int/iris/bitstream/ handle/10665/331475/nCoVsitrep11Mar2020-eng.pdf (accessed on 1 December 2020).

2. Wu, Z.; McGoogan, J.M. Characteristics of and Important Lessons from the Coronavirus Disease 2019 (COVID-19) Outbreak in China: Summary of a Report of 72314 Cases from the Chinese Center for Disease Control and Prevention. JAMA 2020, 323, 1239-1242. [CrossRef]

3. Hodges, C.; Moore, S.; Lockee, B.; Trust, T.; Bond, A. The difference between emergency remote teaching and online learning. Educ. Rev. 2020, 27, 1-7.

4. Dhawan, S. Online Learning: A Panacea in the Time of COVID-19 Crisis. J. Educ. Technol. Syst. 2020, 49, 5-22. [CrossRef]

5. Ariño, A.; Llopis, R.; Martínez, M.; Pons, E.; Prades, A. Via Universitària: Accés, Condicions d'Aprenentatge, Expectatives i Retorns dels Estudis Universitaris (2017-2019), 1st ed.; Xarxa Vives d'Universitats: Barcelona, Spain, 2019.

6. Fardoun, H.; González-González, C.; Collazos, C.A.; Yousef, M. Exploratory Study in Iberomaerica on the Teaching-Learning Process and Assessment Proposal in the Pandemic. Educ. Knowl. Soc. 2020, 21, 1-9.

7. Rahmat, N.H. Innovation in education: Barriers and facilitating factors. Eur. J. Educ. Stud. 2020, 6, 55-66.

8. Asiedu, M.A.; Anyigba, H.; Ofori, K.S.; Ampong, G.O.A.; Addae, J.A. Factors influencing innovation performance in higher education institutions. Learn. Organ. 2020, 27, 365-378. [CrossRef]

9. López, E.P.; Atochero, A.V.; Rivero, S.C. Educación a distancia en tiempos de COVID-19: Análisis desde la perspectiva de los estudiantes universitarios. RIED Revista Iberoamericana de Educación a Distancia 2020, 24, 331-350. [CrossRef]

10. Fernández, A.; Paricio, J.; Ibarra-Sáiz, M.S.; Rodríguez-Gómez, G. No Es Cuestión de Medios, Sino de Modelo: Escenarios de Reducción de la Presencialidad en la Enseñanza Universitaria; Red Estatal de Docencia Universitaria: Zaragoza, Spain, 2020.

11. UNESCO-IESALC. COVID-19 y Educación Superior: De los Efectos Inmediatos al Día Después. Análisis de Impactos, Respuestas Políticas y Recomendaciones. 2020. Available online: http:/ /www.iesalc.unesco.org/wp-content/uploads/2020/05/COVID19-ES-130520.pdf (accessed on 3 December 2020).

12. La Velle, L.; Newman, S.; Montgomery, C.; Hyatt, D. Initial teacher education in England and the Covid-19 pandemic: Challenges and opportunities. J. Educ. Teach. 2020, 46, 596-608. [CrossRef]

13. Domínguez, M.; Rodríguez, N. Adaptación exprés a la actividad pedagógica no presencial durante la pandemia. CIVINEDU 2020, 1, 665-668.

14. Álvarez-Álvarez, C.; García-Prieto, F.J. Brecha digital y nuevas formas académicas en la escuela rural española durante el confinamiento. Educar 2021, in press.

15. Garcia-Marcos, C.J.; López-Vargas, O.; Cabero-Almenara, J. Autorregulación del aprendizaje en la Formación Profesional a Distancia: Efectos de la gestión del tiempo. Rev. Educ. Distancia 2020, 20, 1-21. [CrossRef]

16. Hazim Torres, J.A.; Febles Rodríguez, J.P.; Febles Estrada, A. Estándares para evaluar la calidad de cursos virtuales en la Educación Superior. UCE Ciencia Revista de Postgrado 2019, 7. Available online: http:/ / uceciencia.edu.do/index.php/OJS/article/view/154 (accessed on 14 December 2020).

17. Sinclair, G.; McClaren, M.; Griffin, M.J. E-Learning and Beyond a Discussion Paper. Available online: http:/ / citeseerx.ist.psu. edu/viewdoc/summary?doi=10.1.1.135.9118 (accessed on 30 November 2020). 
18. Cobo, C.; Pardo, H. Planeta Web 2.0. Inteligencia colectiva o medios fast food. Cuad. Pesqui. 2007, 39, 688-693.

19. Redecker, C. Review of Learning 2.0 Practices: Study on the Impact of Web 2.0 Innovations on Education and Training in Europe. Available online: https:/ / core.ac.uk/download/pdf/38614626.pdf (accessed on 14 December 2020).

20. Ruhe, V.; Zumbo, B.D. Evaluation in Distance Education and E-Learning; The Guildford Press: New York, NY, USA, 2009.

21. Pomares, J.; García Gómez, G.J.; Lorenzo, G.; Lledó, A.; Roig-Vila, R. Gestión de Calidad, Autoaprendizaje y Docencia Virtual en el Máster Universitario en Automática y Robótica; Ediciones Octaedro S.L.: Barcelona, Spain, 2017.

22. Del-Arco, I.; Flores, Ò.; Silva, P. El desarrollo del modelo flipped classroom en la universidad: Impacto de su implementación desde la voz del estudiantado. Rev. Investig. Educ. 2019, 37, 451-469. [CrossRef]

23. Camilloni, A.R.W.; Celman, S.; Litwin, E.; Palou de Maté, M.C. La Evaluación de los Aprendizajes en el Debate Didáctico Contemporáneo; Paidós: Buenos Aires, Argentina, 1998.

24. Tobin, T.J. Best Practices for Administrative Evaluation of Online Faculty. Online J. Distance Learn. Adm. 2004, 7, 1-12.

25. Constantino, G.D.; Llull, L. Evaluación y calidad en los programas y cursos online en la enseñanza superior. Eur. J. Res. Educ. Teach. 2015, 7, 225-233.

26. Felten, P. Principles of good practice in SoTL. Teach. Learn. Inq. ISSOTL J. 2013, 1, 121-125. [CrossRef]

27. Ramírez Garzón, M.I.; Montoya Vargas, J. La evaluación de la calidad de la docencia en la universidad: Una revisión de la literatura. REDU Rev. Docencia Univ. 2014, 12, 77-95. [CrossRef]

28. Fenstermacher, G.D.; Richardson, V. On Making Determinations of Quality in Teaching. Teach. Coll. Rec. 2005, 107, 186-213. [CrossRef]

29. Yang, Y.; Cornelius, L.F. Students' perceptions towards the quality of online education: A qualitative approach. Assoc. Educ. Commun. Technol. 2004, 1, 861-877.

30. Smart, K.L.; Capel, J.J. Students' perceptions of online learning: A comparative study. J. Inf. Technol. Educ. Res. 2006, 5, 201-219. [CrossRef]

31. Rodríguez, M.C.; Ooms, A.; Montáñez, M. Students' perceptions of online-learning quality given comfort, motivation, satisfaction, and experience. J. Interact. Online Learn. 2008, 7, 105-125.

32. Lee, J.; Martin, L. Investigating Students' Perceptions of Motivating Factors of Online Class Discussions. Int. Rev. Res. Open Distrib. Learn. 2017, 18, 148-172. [CrossRef]

33. Guri-Rosenblit, S. E-Teaching in Higher Education: An Essential Prerequisite for E-Learning. J. New Approaches Educ. Res. 2018, 7, 93-97. [CrossRef]

34. Almenara, J.C. Formación del profesorado universitario en TIC. Aplicación del método Delphi para la selección de los contenidos formativos. Educación XX1 2013, 17, 111-132. [CrossRef]

35. Cabero, J.; Barroso, J. ICT teacher training: A view of the TPACK model /Formación del profesorado en TIC: Una visión del modelo TPACK. Cult. y Educac. 2016, 28, 633-663. [CrossRef]

36. Santos, A.R.P.; Peña, O.C.; Camargo, C.A. Hacia la transformación de la práctica docente: Modelo espiral de competencias TICTACTEP. Pixel Bit Rev. Medios y Educac. 2017, 51, 37-51. [CrossRef]

37. Comisión Europea. Digital Education Action Plan 2021-2027: Resetting Education and Training for the Digital Age. Available online: https://ec.europa.eu/education/sites/education/files/document-library-docs/deapcommunication-sept2020_en.pdf (accessed on 19 December 2020).

38. Muñoz, L.V.A.; Cárdenas-Rodríguez, R.; Terrón-Caro, T. Introducción = Introduction. Rev. Humanid. 2017, 31, 13. [CrossRef]

39. Prendes, M.P.; Martínez Sánchez, F.; Gutiérrez Porlán, I. Competencia digital: Una necesidad del profesorado universitario en el siglo XXI. RED Rev. Educ. Distancia 2017, 56, 1-22. [CrossRef]

40. Montes, R.; Rodríguez-Pina, G.; González, M.; Gea, M. Enseñanza y Recursos de Aprendizaje Abiertos: Recomendaciones de Procedimientos Basados en Modelos de Calidad; Proceedings III Congreso Iberoamericano Sobre Calidad y Accesibilidad de la Formación Virtual, Alcalá de Henares, Spain, 25 April 2012; Bengochea, L., Hilera, J.R., Eds.; Universidad de Alcalá Ediciones: Alcalá de Henares, Spain, 2012; pp. 386-393.

41. García-Planas, M.I.; Taberna, J. The transition from the classroom to non-classroom teaching at the UPC during the COVID-19 pandemic. Int. J. Educ. Res. Innov. 2020, 15, 177-187. [CrossRef]

42. González-García, S.; Casadelvalle, I.; Urda, M.O.; Fortún, T.; Mezquía de Pedro, N.; Melón, R.G. Un reto en tiempos de pandemia para la educación médica en Cuba. Educ. Médica Super. 2020, 34, 1-13.

43. Tejedor, S.; Cervi, L.; Tusa, F.; Parola, A. Educación en tiempos de pandemia: Reflexiones de alumnos y profesores sobre la enseñanza virtual universitaria en España, Italia y Ecuador. Rev. Lat. Comun. Soc. 2020, 78, 1-21. [CrossRef]

44. Salinas, J. Modelos flexibles como respuesta de las universidades a la sociedad de la información. Acción Pedagógica 2002, 11, 4-13.

45. Salinas, J. Teaching innovation and the use of ICT in university education. RUSC Univ. Knowl. Soc. J. 2004, 1, 1-16. [CrossRef]

46. Samaniego, G.; Marqués, L.; Gisbert, M. El profesorado universitario y el uso de Entornos Virtuales de aprendizaje. Campus Virtuales 2015, 4, 50-58.

47. Maor, D.; Currie, J.K. The use of technology in postgraduate supervision pedagogy in two Australian universities. Int. J. Educ. Technol. High Educ. 2017, 14, 1. [CrossRef]

48. Mercader, C.; Sallán, J.G. ¿Cómo utiliza el profesorado universitario las tecnologías digitales en sus aulas? REDU Rev. Docencia Univ. 2017, 15, 257-274. [CrossRef] 
49. Centeno, C.; Herrero, E. Factores de Éxito en el E-Learning. 2005. Available online: https://www.educaweb.com/noticia/2005/0 9/26/factores-exito-learning-678/ (accessed on 14 December 2020).

50. Zapata, M. Sistemas de educación a distancia a través de redes. Unos rasgos para la propuesta de evaluación de la calidad. RED Rev. Educ. Distancia 2003, 9, 1-18.

51. Vázquez-Cano, E.; Urrutia, M.L.; Parra-González, M.E.; Meneses, E.L. Analysis of Interpersonal Competences in the Use of ICT in the Spanish University Context. Sustainability 2020, 12, 476. [CrossRef]

52. OCDE. TALIS 2018 Results (Volume I): Teachers and School Leaders as Lifelong Learners. Available online: http: / www.oecd. org/education/talis-2018-results-volume-i-1d0bc92a-en.htm (accessed on 18 November 2020).

53. Trigueros, R.; Navarro, N. La influencia del docente sobre la motivación, las estrategias de aprendizaje, pensamiento crítico de los estudiantes y rendimiento académico en el área de Educación Física. Psychol. Soc. Educ. 2019, 11, 137-150. Available online: http:/ / ojs.ual.es/ojs/index.php/psye/article/view/2230 (accessed on 1 December 2020). [CrossRef]

54. Azogue-Punina, J.G.; Barrera-Erreyes, H.M. La motivación intrínseca en el aprendizaje significativo. Polo del Conocimiento: Rev. Científico-Prof. 2020, 5, 99-116.

55. Ruiz-Alfonso, Z.; León, J.; Santana-Vega, L.; González, C. Teaching Quality: Relationships between Students' Motivation, Effort Regulation, Future Interest, and Connection Frequency. Psicología Educativa 2020, 27, 67-76. [CrossRef]

56. Rosseel, Y. Lavaan: An R Package for Structural Equation Modeling and More. Version 0.5-12 (BETA). J. Stat. Softw. 2012, 48, 1-36. Available online: https://www.jstatsoft.org/article/view/v048i02 (accessed on 2 December 2020). [CrossRef]

57. R Core Team. R: A Language and Environment for Statistical Computing; R Foundation for Statistical Computing: Vienna, Austria, 2018; Available online: https: / /www.R-project.org (accessed on 3 December 2020).

58. Epskamp, S. semPlot: Unified Visualizations of Structural Equation Models. Struct. Equ. Model. Multidiscip. J. 2015, 22, 474-483. [CrossRef]

59. Del Arco, I.; Silva, P.; Flores, O. University Teaching in Times of Confinement: The Light and Shadows of Compulsory Online Learning. Sustainability 2021, 13, 375. [CrossRef]

60. Martín, B.R. Docencia Colaborativa Universitaria: Planificar, Gestionar y Evaluar con Entornos Virtuales de Aprendizaje; Ediciones de la Universidad Castilla la Mancha: Cuenca, Spain, 2020.

61. Área Moreira, M. El diseño de cursos virtuales: Conceptos, enfoques y procesos pedagógicos. Educ. Tecnol. 2020, 3, 67-86.

62. Mercader, C. Las Tecnologías Digitales en la Docencia Universitaria. Barreras Para su Integración. Ph.D. Thesis, Universidad Autónoma de Barcelona, Cerdanyola del Vallés, Barcelona, Spain, 2018.

63. De Vries, S.; Van De Grift, W.J.; Jansen, E.P. How teachers' beliefs about learning and teaching relate to their continuing professional development. Teach. Teach. 2013, 20, 338-357. [CrossRef]

64. Mercader, C. Las resistencias del profesorado universitario a la utilización de las tecnologías digitales. Aula Abierta 2019, 48, 167-174. [CrossRef]

65. García-Peñalvo, F.J. Modelo de referencia para la enseñanza no presencial en universidades presenciales. Campus Virtuales 2020, 9, 41-56.

66. Grande, A. La necesaria actualización del Proyecto docente universitario. Rev. Investig. Innovación Educ. 2020, 1, $24-25$.

67. García, A. COVID-19 y educación a distancia digital: Preconfinamiento, confinamiento y postconfinamiento. RIED Rev. Iberomam. Educ. Distancia 2020, 24, 9-32. 